\title{
Exposure to ochratoxin A through consumption of grape juices produced by steam distillation method and intended for school meals
}

\author{
Exposição à ocratoxina A através do consumo de sucos de uva produzidos \\ pelo método de destilação a vapor e destinados para a merenda escolar
}

\author{
Bruna Dachery ${ }^{\mathrm{I}}$ Vitor Manfroi ${ }^{\mathrm{I}}$ Juliane Elisa Welke $^{\mathrm{I}}$
}

- NOTE -

\section{ABSTRACT}

The grape juice was included in meals of public schools in the states of Rio Grande do Sul and Santa Catarina Brazil. The juices intended for schools have been produced by small wineries through the steam distillation method. This method presents a particularity in relation to other juice production methods, since the grapes are not macerated to extract the juice. In literature is well established that maceration of grapes is the main critical point associated with the ochratoxin A (OTA) contamination in juices. OTA is a mycotoxin with nephrotoxic and immunosuppressives effects. The aim of this study was to verify the OTA occurrence in juices produced by steam distillation method, as grape juice may be a source of OTA exposure for children. No sample showed OTA levels higher than the detection limit $\left(0.05 \mu \mathrm{g} \mathrm{L}^{-1}\right)$ of method used to determine this toxin. This study demonstrated the adequate quality of juice produced by this extraction method. Furthermore, data about OTA occurrence are important to support risk assessment studies related to the exposure to toxic compounds through diet.

Key words: mycotoxins, toxic compounds, ochratoxin A.

\section{RESUMO}

O suco de uva foi incluido nas refeições de escolas públicas do estado do Rio Grande do Sul e Santa Catarina, Brasil. O suco destinado para as escolas é produzido por pequenas vinicolas através do método de arraste a vapor. Este método apresenta uma particularidade em relação aos demais métodos de produção do suco, pois as uvas não são maceradas para a extração do mosto. Cabe salientar que a maceração das uvas é o principal ponto crítico relacionado à contaminação dos sucos com ocratoxina A (OTA), que é uma micotoxina que apresenta efeitos nefrotóxicos e imunossupressores. $O$ objetivo deste estudo foi verificar a ocorrência de OTA em sucos produzidos pelo método de arraste de vapor, pois o suco de uva pode ser uma fonte de exposição à OTA para crianças. Nenhuma amostra apresentou
OTA em niveis maiores que o limite de detecção $\left(0,05 \mu g L^{-1}\right)$ do método usado para determinar esta toxina. Este resultado evidenciou a qualidade adequada do suco produzido por este método de extração. Além disso, dados sobre a ocorrência de OTA são importantes para subsidiar estudos relacionados à exposição a compostos tóxicos através da dieta.

Palavras-chave: micotoxina, compostos tóxicos, ochratoxin A.

Ochratoxin A (OTA) is a mycotoxin produced by filamentous fungi, such as Aspergillus niger and A. carbonarius. Exposure to OTA through food consumption poses a health risk, since this mycotoxin has been related to nephrotoxicity (DAI et al., 2014). The International Agency for Research on Cancer (IARC) classified OTA as possible carcinogen to humans (IARC, 1993). The Joint FAO/ WHO Expert Committee on Food Additives (JECFA) established a provisional tolerable weekly intake of $112 \mathrm{ng} \mathrm{kg}^{-1}$ body weight (bw), which corresponds to approximately $16 \mathrm{ng} \mathrm{kg}^{-1}$ bw per day (JECFA, 2007).

The occurrence of OTA in grapes and juice has been associated to the climate conditions of grape cultive, maturation degree and physical damage on grapes (WELKE et al, 2009). The concern related to the OTA exposure through daily consumption of grape juice by children is due to the inclusion of this beverage in meals of public schools of Rio Grande do Sul and Santa Catarina states, Brazil. This approach was adopted via legislation and aims: (i) the offering of healthy products for children and

\footnotetext{
'Instituto de Ciência e Tecnologia de Alimentos, Universidade Federal do Rio Grande do Sul (URFGS), Av. Bento Gonçalves, n. 9500, 91501-970, Porto Alegre, RS, Brasil. E-mail: juliane.welke@ufrgs.br. "Corresponding author. 
(ii) stimulate the sector of grape derivatives (RIO GRANDE DO SUL, 2009). Then, small producers of familiar agrobusiness have been stimulated to attend this demand through juice production.

Three methods have been used to obtain grape juice such as Welch, Flanzy and steam distillation method. The first two methods are mainly used in industrial scale. The Welch method involves the heating of grapes at $65^{\circ} \mathrm{C}$ followed by the addition of pectolytic enzymes, which remain in contact with the juice for one to two hours at $60^{\circ} \mathrm{C}$. Then, the juice is pasteurized and bottled. The Flanzy method can also be called as sulphurous maceration. In this procedure the grape is crushed in a saturated sulfur dioxide environment for a few days, followed by pasteurization and bottling (MARZAROTTO, 2010).

The steam distillation is the most used method to produce grape juice by small producers in the Rio Grande do Sul state, Brazil. This technique has low cost of implementation and is used by about 400 agribusinesses in the state, resulting in 8 million liters of juice per year (IBRAVIN, 2015). The steam distillation system is formed by a water tank, which is heated to produce steam. A container with grapes is located above of water tank. The steam achieves the grapes through a small hole that connect the two containers (water and grape). Furthermore, this apparatus has a lateral opening to drain the juice that is bottled (MARZAROTTO, 2010).

Recently, the Brazilian legislation established limits for some mycotoxins in various products including OTA in grape juice. The maximum limit established for grape juices and wines is $2 \mu \mathrm{g} \mathrm{L}{ }^{-1}$ (ANVISA, 2011). The studies about the occurrence of OTA in Brazilian juices are incipient. Literature data are mainly related to juice produced by enzymatic method (also called as Welch) (ZIMERLI E DICK, 1996; ROSA et al., 2004; SHUNDO et al., 2006; LEE et al., 2012; CAO et al., 2013).

Researches on the OTA determination in grape juice produced by steam distillation method were not reported in literature. In this way, the objective of this study was to verify the occurrence of OTA in grape juice produced using steam distillation, which is the method widely used by small wineries of Rio Grande do Sul State, Brazil. This approach allows evaluating the exposure to this mycotoxin through consumption of grape juice intended for school meals.

For this proposal, 41 samples of juice produced using the following grape varieties were analyzed: Bordô (15 samples), Concord (17 samples) and Niágara Rosada (9 samples). These samples harvested in the years 2010, 2011 and 2012 in Serra Gaúcha region were used to obtain juice by steam distillation method.

OTA was extracted following the developed and validated method by WELKE et al. (2010) and samples were analyzed using high performance liquid chromatography (HPLC) with fluorescence detector (Agilent series 1100, USA) that was equipped with an online degasser, a quaternary pump, and an automatic injector (Figure 1A-C). For fluorescent detection of OTA the excitation wavelength was $333 \mathrm{~nm}$, and the emission wavelength was $443 \mathrm{~nm}$. A C18 column (XBridgeTM Shield RP $18 ; 5 \mu \mathrm{m} ; 4.6 \times 150 \mathrm{~mm}$, Waters, Irleand) and the following mobile phase (acetonitrile: water: acetic acid, 99:99:2, v/v/v) were used in HPLC. The analysis was performed under isocratic conditions at a flow rate of $1 \mathrm{~mL} \mathrm{~min}$. The same conditions were used in high performance liquid chromatography-tandem mass spectrometry (HPLC-MS/MS, micrOTOF-Q III, USA) for confirmation of OTA (Figure 1D). Recuperation of the method was $96 \%$ and $98 \%$ for the levels of 1 and $2 \mathrm{ug} \mathrm{L} \mathrm{L}^{-1}$ with a standard deviation of 6.1 and $5.4 \%$, respectively. The LOD and LOQ were 0.05 and $0.08 \mu \mathrm{g} \mathrm{L}^{-1}$ respectively. The validation results confirm the efficiency of the method, which is sensitive enough to be used in the OTA quantification.

No sample showed OTA levels higher than $0.05 \mu \mathrm{g} \mathrm{L}^{-1}$, which is the limit of detection of the HPLC method. The juices evaluated in this study (produced using steam distillation) presented a particularity in relation to the other methods that may be used to obtain grape juice. In steam distillation, the grapes were not macerated to extract juice, as occurs in welch and Flanzy methods (MARZAROTTO, 2010). Maceration of grapes has been considered a critical control point of OTA contamination in juice, since higher levels of OTA are found in grape skin compared to pulp. Thus, maceration step allows the migration of OTA present in skin to the must used to juice production (DACHERY et al., 2015).

OTA was first reported in grape juice in 1996 and this mycotoxin was found in 8 samples produced in Switzerland with median concentrations amounting to $0.235 \mu \mathrm{g} \quad \mathrm{L}^{-1}$ (ZIMMERLI \& DICK, 1996). CAO et al. (2013) found OTA in $30 \%$ of Chinese grape juice samples in levels ranging from 0.26 to $0.54 \mu \mathrm{g} \mathrm{L}^{-1}$. A greater number of juice samples containing OTA was reported by LEE et al. (2012). The levels found in $91 \%$ of samples marketed in Malasia were of 0.02 to $1.05 \mu \mathrm{g} \mathrm{L}^{-1}$ (LEE et al., 2012). In evaluations of juice produced in Brazil, no sample presented 

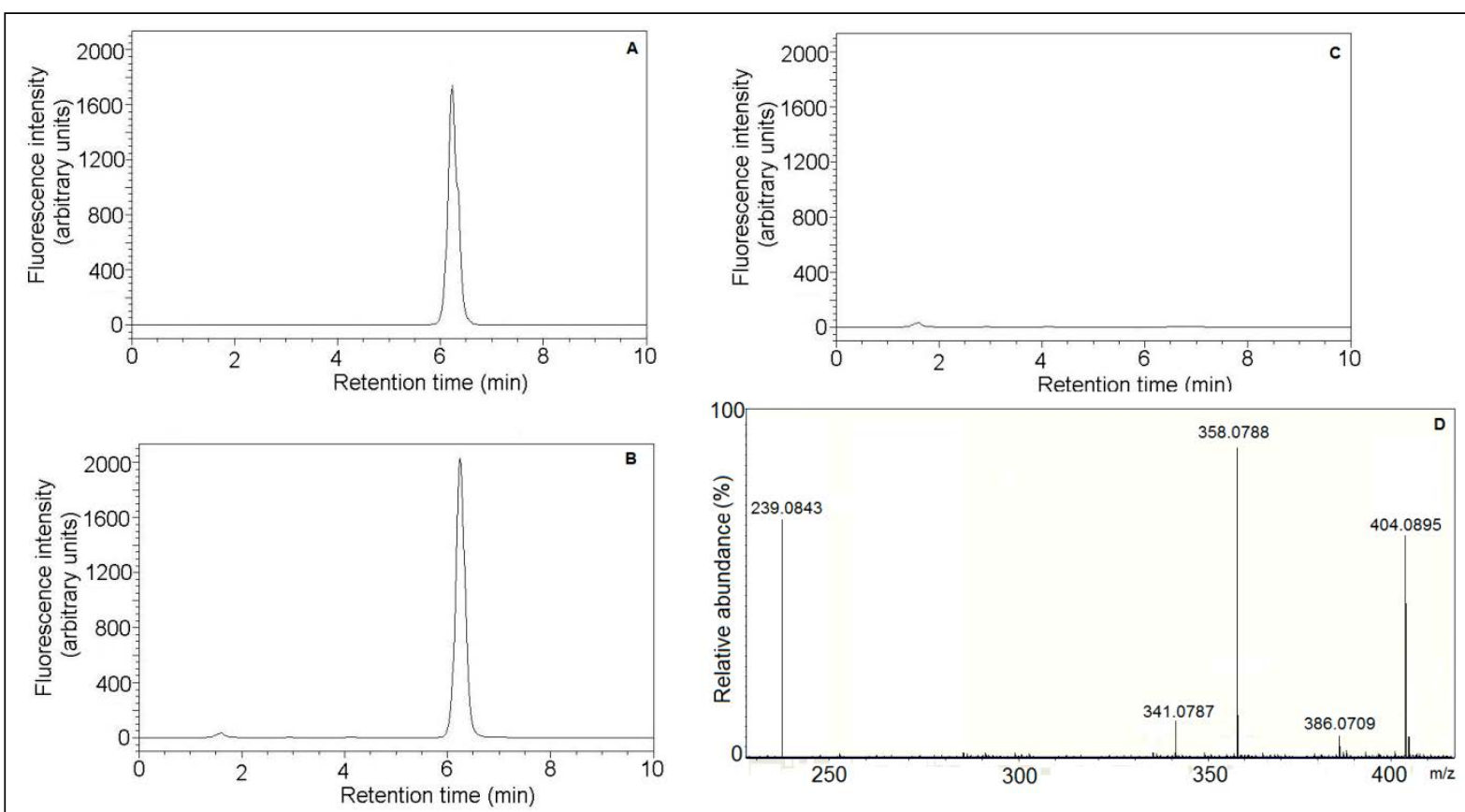

Figure 1 - Chromatogram obtained using high performance liquid chromatography with fluorescence detector after injection of (A) ochratoxin A (OTA) standard solution in concentration of $2 \mu \mathrm{g} \mathrm{L}^{-1}$, (B) organic extract of grape juice spiked with $2 \mu \mathrm{g} \mathrm{L} \mathrm{L}^{-1}$ of OTA and (C) organic extract grape juice without OTA. The MS/MS spectrum of OTA (m/z=403.0823) obtained using (D) high performance liquid chromatography-tandem mass spectrometry (HPLC-MS/MS) is showed in positive mode to confirm OTA: $\mathrm{m} / \mathrm{z} 404.0895\left([\mathrm{M}+\mathrm{H}]^{+}\right), \mathrm{m} / \mathrm{z} 386.0709\left(\left[\mathrm{M}+\mathrm{H}_{-} \mathrm{H}_{2}\right]^{+}\right), \mathrm{m} / \mathrm{z} 358.0788\left([\mathrm{M}+\mathrm{H}-\mathrm{HCOOH}]^{+}\right), \mathrm{m} / \mathrm{z} 341.0787([\mathrm{M}+\mathrm{H}-\mathrm{HCOOH}-$ $\left.\left.\mathrm{NH}_{3}\right]^{+}\right)$and $\mathrm{m} / \mathrm{z} 239.0843\left([\mathrm{M}+\mathrm{H}-\text { fenilalanina }]^{+}\right)$.

OTA levels above the maximum limit established by Brazilian legislation $\left(2 \mu \mathrm{g} \mathrm{L} \mathrm{L}^{-1}\right)$ (ROSA et al., 2004; SHUNDO et al., 2006). ROSA et al. (2004) analyzed 64 grape juice samples marketed in Rio de Janeiro city, Brazil. OTA was found in $25 \%$ of samples and the maximum level was $0.1 \mu \mathrm{g}$ $\mathrm{L}^{-1}$. SHUNDO et al. (2006) evaluated 38 grape juices produced in Brazil and OTA was not found in samples. Other data on occurrence of OTA may be checked in recently review published by DACHERY et al. (2015), in which the exposure levels related to consumption of grape juice containing OTA were reported.

This study demonstrated the adequate quality of juice samples produced by the method of steam distillation. The no detectable levels of OTA confirmed the safety of these juices intended for meals of several schools of Brasil and the low exposure to this mycotoxin through grape juice. OTA occurrence data are important to support risk assessment studies related to the exposure to toxic compounds through diet. Furthermore, a study to evaluate the effect of steam distillation method on OTA levels of juices produced using naturally contaminated grapes with OTA will conducted.

\section{ACKNOWLEDGMENTS}

The authors thank the Conselho Nacional de Desenvolvimento Científico e Tecnológico (CNPq), the Coordenação de Aperfeiçoamento de Pessoal de Nível Superior (CAPES), and the Fundação de Amparo a Pesquisa do Estado do Rio Grande do Sul (FAPERGS) for financial support and scholarships.

\section{REFERENCES}

ANVISA (AGÊNCIA NACIONAL DE VIGILÂNCIA SANITÁRIA). Resolução RDC n.7, fevereiro de 2011. Diário Oficial da União, Poder Executivo, n.37, 2011.

CAO, J.L. et al. Moleculaly imprinted polymer-based solid phase clean-up for analysis of ochratoxin A in beer, red wine, and grape juice. Journal of Separation Science, v.36, p.1291-1297, 2013. Available from: <http://www.ncbi.nlm.nih.gov/pubmed/23471605>. Accessed: Apr. 20, 2015. doi: 10.1002/jssc.201201055.

DACHERY, B. et al. Occurrence of ochratoxin A in grapes, juices and wines and risk assessment related to this mycotoxin exposure. Ciência Rural, v.46, p.176-183, 2016. Available from: <http:// dx.doi.org/10.1590/0103-8478cr20141711>. Accessed: Jan. 10, 2016. doi: $10.1590 / 0103-8478 \mathrm{cr} 20141711$.

DAI, Q. et al. MicroRNA profiling of rats with ochratoxin A nephrotoxicity. BMC Genomics, v.15, p.333-347, 2014. Available from: <http://dx.doi.org/10.1186/1471-2164-15-333>. Accessed: Apr. 20, 2015. doi: 10.1186/1471-2164-15-333. 
IARC (INTERNATIONAL AGENCY FOR RESEARCH ON CANCER). Some naturally occurring substances, food items and constituents, heterocyclic aromatic amines and mycotoxins. Lyon. World Health Organization, v.56, p.489, 1993

IBRAVIN (INSTITUTO BRASILEIRO DO VINHO). Accessed: Apr. 20, 2015. Online. Available from: <http://www.ibravin.org. br/downloads $>$. Accessed: Apr. 20, 2015.

JECFA. Joint FAO/WHO Expert Committee on Food Additives, 2007. Accessed: Nov. 15, 2014. Online. Available from: $<$ http://www.inchem.org/documents/jecfa/jecmono/v47je01.htm>. Accessed: Apr. 20, 2015.

LEE, T. P. Molecularly imprinted polymer as sorbent in micro-solid phase extraction of ochratoxin A in coffee, grape juice and urine. Talanta, v.88, p.129-135, 2012. Available from: <http://dx.doi org/10.1016/j.talanta.2011.10.021>. Accessed: Apr. 20, 2015. doi: $10.1016 /$ j.talanta.2011.10.021

MARZAROTTO, V. Suco de uva. In: VENTURINI FILHO, W.G. Bebidas não alcoólicas. São Paulo: Edgard Blucher, 2010, p.359-385.

RIO GRANDE DO SUL. Lei $\mathbf{n}^{\circ} \mathbf{1 3 . 2 4 7}$, de 08 de setembro de 2009. Accessed: Oct. 15, 2014. Online. Available from: <http:// www.al.rs.gov.br/legis/>. Accessed: Apr. 20, 2015.

ROSA, C.A.R. et al. Occurrence of ochratoxin A in wine and grape juice marketed in Rio de Janeiro, Brazil. Food Additives and
Contaminants, v.21, p.358-364, 2004. Available from: <http:// dx.doi.org/10.1080/02652030310001639549>. Accessed: Oct. 15, 2014. doi: 10.1080/02652030310001639549.

SHUNDO, L. et al. Ochratoxin A in wines and grape juices commercialized in the city of SãoPaulo, Brazil. Brazilian Journal of Microbiology, v.37, p.533-537, 2006. Available from: <http:// dx.doi.org/10.1590/S1517-83822006000400024>. Accessed: Oct. 15, 2014. doi: 10.1590/S1517-83822006000400024.

WELKE, J.E. et al. Determination of ochratoxin A in wine by highperformance thin-layer chromatography using charged coupled device. Journal of the Brazilian Chemical Society, v.21, p.441446, 2010. Available from: <http://dx.doi.org/10.1590/S010350532010000300007>. Accessed: Oct. 15, 2014. doi: 10.1590/ S0103-50532010000300007.

WELKE, J.E. et al. Aspects related to the presence of toxigenic fungi in grapes and ochratoxin A in wines. Ciência Rural, v.39, n.8, p.2567-2575, 2009. Available from: <http://dx.doi. org/10.1590/S0103-84782009005000201>. Accessed: Oct. 15, 2014. doi: 10.1590/S0103-84782009005000201.

ZIMMERLI, B.; DICK, R. Determination of ochratoxin A at the ppt level in human blood, serum, milk and some foodstuffs by high performance liquid chromatography with enhanced fluorescence detection and immunoaffinity column cleanup: methodology and Swiss data. Journal of Chromatography B, v.666, p.85-99, 1996. Available from: <http://www.tandfonline.com/doi/abs/10.1080/0265203960937 4451>. Accessed: Oct. 15, 2014. doi: 10.1080/02652039609374451. 